2.Korol, I. and Poltorak, A. (2018). Financial risk management as a strategic direction for improving the level of economic security of Ukraine. Baltic Journal of Economic Studies, 4, 1(2018), 235-241. http://dx.doi.org/10.30525/2256-0742/2018-4$1-235-241$

3.Atamanyuk, I. P. (2002). Polynomial algorithm for optimal extrapolation of the parameters of stochastic systems. Upravlyayushchiye sistemy i mashiny, 1, 16-19.

4.Atamanyuk, I. P., Sirenko, N. N., Baryshevskaya, I. V. (2012). Information technology for managing an agricultural enterprise based on forecasting its economic condition. Vostochno-yevropeyskiy zhurnal peredovikh tekhnologiy, 6/4 (60), 6874.

5.Kryukov, A. D. (2012). Doslidzhennya vplyvu skladovykh oborotnykh aktyviv pidpryyemstva na yoho finansovi rezul'taty na osnovi korelyatsiyno-rehresiynoho analizu. Upravlinnya rozvytku, 2, 138-140.

6. Metodychni rekomendatsiyi shchodo kompleksnoyi otsinky obsyahiv neproduktyvnoho vidplyvu (vyvezennya) finansovykh resursiv za mezhi Ukrayiny vid 24.03.2015 r. № 286. Retrieved from https://zakon.rada.gov.ua/rada/show/v0286731-15.

7.Poltorak, A. and Zaiko, A. (2018). Methodological principles of the state's financial security systematization. Agrosvit, 21, 5-71. DOI: 10.32702/2306-6792.2018.21.65

8.Poltorak, A., Palamarchuk, V. and Manukian, T. (2018). Development of the mechanism of lending for higher education as a way to strengthen the level of the state's financial security. Investytsiyi: praktyka ta dosvid, 23, 44-49. DOI: 10.32702/23066814.2018.23.44

9.Poltorak, A. S. (2018). Systematic taxonomy of financial security. Visnyk ahrarnoyi nauky Prychornomorya, 3. DOI: $10.31521 / 2313-092 X / 2018-3(99)$

10. Pro zatverdzhennya Metodychnykh rekomendatsiy shchodo rozrakhunku rivnya ekonomichnoyi bezpeky Ukrayiny : nakaz Ministerstva ekonomichnoho rozvytku i torhivli Ukrayiny vid 29.10.2013 r. № 1277. Retrieved from http://document.ua/prozatverdzhennja-metodichnih-rekomendacii-shodo-rozrahunku-doc168080.html.

11. Rohanova, H. O. (2009). Modeling of Working Capital of Enterprises by Methods of Statistical Analysis. Torhivlya i rynok Ukrayiny, 27, 476-484.

Рецензент д.е.н., профессор Дубініна М.В.

UDC 336.761

Polishchuk V.., PhD, Associate Professor

Hryhoruk T.

Huzar O.

Lutsk National Technical University

\title{
MANAGEMENT FEATURES OF BIGL IN THE CONTEXT OF FINANCIAL ENGINEERING
}

The article explores the possibilities of introducing financial instruments on the government securities market of Ukraine. The dynamics of changes and the structure of the state debt of Ukraine, the structure of the owners of BIGL of the country are studied. The directions of institutional corrections of the domestic government loan market in Ukraine are justified. The main factors affecting the issue and circulation of government securities are identified. The foreign experience of introducing debt programs at the state level is analyzed.

Keywords: government securities market, bonds of internal government loan (BIGL), government debt, budget deficit, government debt policy, financial engineering.

Поліщук В.Г., Григорук Т.О. Гузар О.В.

\section{ОСОБЛИВОСТІ УПРАВЛІННЯ ОВДП В КОНТЕКСТІ ФІНАНСОВОГО ІНЖИНІРИНГУ}

В статті досліджено можливості впровадження фінансових інструментів на ринку державних цінних паперів України. Вивчено динаміку зміни та структуру державного боргу України, структуру власників ОВДП країни. Обгрунтовано напрями інституційних корекцій ринку облігацій внутрішніх державних позик в Україні. Визначено основні чинники, що впливають на випуск та обіг державних цінних паперів. Проаналізовано зарубіжний досвід впровадження боргових програм на державному рівні.

Ключові слова: ринок державних цінних паперів, облігації внутрішньої державної позики (ОВДП), державний борг, дефіцит бюджету, боргова політика держави, фінансовий інжиніринг.

Полищук В.Г., Григорук Т.А., Гузар О.В. 


\section{ОСОБЕННОСТИ УПРАВЛЕНИЯ ОВГЗ В КОНТЕКСТЕ ФИНАНСОВОГО ИНЖИНИРИНГА}

В статье исследованы возможности внедрения финансовых инструментов на рынке государственных ценных бумаг Украины. Изучена динамика изменения и структуру государственного долга Украины, структуру собственников ОВГЗ страны. Обоснованы направления институциональных коррекций рынка облигаций внутренних государственных займов в Украине. Определены основные факторы, влияющие на выпуск и обращение государственных ценных бумаг. Проанализирован зарубежный опыт внедрения долговых программ на государственном уровне.

Ключевые слова: рынок государственных ценных бумаг, облигации внутреннего государственного займа (ОВГЗ), государственный долг, дефицит бюджета, долговая политика государства, финансовый инжиниринг.

Formulation of the problem. The emergence of new financial instruments in an innovative form allows us to adequately respond to changes in financial markets of varying complexity, as well as stabilize processes at the macroeconomic level. Despite the emergence of new financial instruments, it is necessary to pay attention to the theoretical processing and practical application of such an important instrument in the debt securities market as domestic government loan bonds.

Analysis of recent research and publications. On the question of research and characteristics of domestic government loan bonds repeatedly addressed such as the leading domestic scientists Dropa Ya.B., Zarutska O.P. Koblyk I.I., Mogylko L.V., Protsko A.V., Tarasiuk M.V., Timoshenko N.M. et al. An analysis of the works published based on the results of scientific developments in this direction indicates the unresolved problem at the moment and requires further research.

Formulating the aims of the article. The purpose of the study is the possibility of introducing financial instruments on the government securities market of Ukraine, using foreign experience in introducing debt programs at the state level.

Presenting main material. Financial engineering involves the creation (design) of new financial products (innovations), the provision of new financial services; uses securities and financial instruments in the form of contracts to create their hybrid and synthetic combinations; used to manage risk, liquidity and profitability; the redistribution of monetary resources and information, provides for the development of optimization schemes for financial in general and tax in particular, production and marketing activities, taking into account legislative and market imperfections [2].

Financial innovations, like any other, can be divided into:

-development innovations, the purpose of which is to increase the competitiveness of the product and the business entity in the future. Such innovations are caused by promising forecasts of economic activity, for example, forecasts of loss of competitiveness of a product, a fall in the image of an economic entity, its possible bankruptcy;

-new operations, which include forms of control and accounting for the movement of cash and securities (money substitutes), methods of planning financial indicators, a methodology for drawing up financial plans of various kinds (balance of income and expenses, cash flow plan, budgeting, operational financial plans, etc. .p), methods of financial analysis, forms of organizing the financial work of an economic entity, interactive and other similar capital investments and other actions related to an attempt to capture an economic the subject of the action for new financial markets;

-crisis innovations, the main sign of which is the solution to the problem of selling a product (work, service) due to a drop in demand for it and a decrease in its sales, as well as a difficult problem - the survival of an economic entity in the market in the conditions of fierce competition. Crisis innovation is aimed at eliminating the organizational, production, economic or financial crisis of an economic entity; 
-new financial products, which are a form of materialization of such financial transactions that have an imperceptible form, so they cannot be sold. They are embodied in the form of instructions, rules, guidelines, formulas, schedules, that is, a specific document, which, in turn, is a financial product, and therefore, the object of sale [3; 13].

Consider the foreign experience in managing government debt securities in the context of financial engineering. To preserve national savings and create conditions for citizens to invest in government bonds abroad, special government programs are played that enable small and medium-sized businesses to organize the savings of employees [8].

In Canada, the New Canada Savings Bonds Program was founded in 1946. CSBs were presented as part of the post-war funding program in Canada. The program provided economic funding for the government and served as a savings for Canadians. Over the years of its existence, the program has changed in terms of terms and methods of raising funds, in particular, it provided the possibility of early withdrawal of funds and accrued interest, payment of interest on a monthly basis or every year. But according to the decision of the Government of Canada, from November 2017 there will not be new issues of Canada Savings Bonds [12]. A similar savings program in the UK TSB, which offers investments in fixed bonds.

The government domestic borrowing market in Ukraine includes a set of debt securities issued by government bodies in agreement with the NBU and is now represented in Ukraine by such types as BIGL, local loan bonds and treasury bonds. Owners of BIGL in Ukraine are the NBU, banks, non-residents, and other groups of owners. In general, domestic government borrowing consists of debt to legal entities and individuals. In addition, BIGL are issued on the primary stock market. Profitability in the primary market tends to decrease. Transactions in the BIGL secondary market include refinancing of NBU banks (repos) loans granted to business entities, which may also include repos; purchase and sale by business entities at the bidding of the organizers of the purchase of government bonds; purchase/sale by government entities of BIGL without intermediaries, organizers of trade [7].

Government bonds of Ukraine are divided into bonds of internal government loans of Ukraine, bonds of external government loans of Ukraine, treasury bonds and target bonds of domestic government loans of Ukraine. BIGL are government securities placed exclusively on the domestic stock market and confirm Ukraine's obligation to reimburse the bearers of these bonds with their nominal value with payment of income in accordance with the terms of the bond placement.

The main issues related to the features of the mechanism of the yield of BIGL in Ukraine are thoroughly covered in Protsko O.V. [11]. In particular, it stated the limitations of modern theoretical concepts to explain the processes and phenomena generated by the structural and functional transformations of government securities markets in the context of global financial instability, substantiates the need to analyze a specific configuration of financial instability risks, which objectively determines the expansion of the state's financial capabilities to stabilize national financial system using government securities boom city With this in mind, an alternative theoretical approach to the study of the government securities market is proposed, based on the dependence of the structural and functional parameters of the specified market on the accumulated macro-financial deformations. The proposed approach allowed us to study the main pricing factors and determine the adequacy of pricing at government bonds [6].

In accordance with its authority, the Ministry of Finance:

-develops and publishes indicative BIGL placement schedules, determines the time and volume of bonds placement (the schedule is approved, as well as changes to it are periodically posted on the Ministry's official website)

-determines the forms and ways of placement of BIGL, sets the terms of circulation of BIGL, the dates of their repayment and payment of coupon income (for coupon bonds)

-establishes the maximum level of yield on government bonds, according to which the applications of participants in the bond placement are satisfied;

-publishes information on the results of the placement of BIGL; 
-issues of BIGL with global certificates;

-provides timely repayment of BIGL and payment of income on them [9].

The placement of BIGL is carried out based on the current funding needs of the State Budget of Ukraine. More recently, Ukrainian BIGL enjoyed a low degree of confidence among investors, was the result of the influence of the following factors: low yield and negative expectations regarding its growth for limited budgetary resources for debt servicing; the probability of timely repayment of debts on past issues is not high; a high risk of hryvnia devaluation and, as a result, a decrease in government securities income [5]. It is worth noting that the National Bank of Ukraine in 2018 created additional conditions for the activation of the government bonds market of Ukraine by improving the mechanism for the initial placement of BIGL.

Firstly, primary dealers got the opportunity to act as a broker for their customers, buying BIGL at their initial placement on their own behalf, on behalf of and at the expense of their customers.

Secondly, it became possible to credit bonds to the primary dealer's own securities account in case of untimely transfer or non-transfer of funds by the client.

Thirdly, the period during which funds from participants in the placement of bonds can be received has increased from two business days to five.

These changes were approved by the Resolution of the NBU Board dated June 26, 2018 No. 72 "On approval of the Amendments to the Regulation on the procedure for conducting operations related to the placement of bonds of internal government loans".

As of September 1, 2019, the total number of bonds of the domestic state loan is $699,859,138$, the average maturity of government bonds is 3855 days, the borrowing currencies are Ukrainian hryvnias, euros or US dollars, the repayment dates are the dates from September 2019 to November 2047, the nominal level of profitability ranges from 6-19\% in hryvnias.

You can buy government bonds as follows. Select an agent for the purchase of government bonds among primary dealer banks or securities traders licensed by the National Securities and Stock Market Commission. The list of primary dealer banks is as follows: Ukrgasbank AB, Oschadbank JSC, Raiffeisen Bank Aval JSC, UkrSibbank JSC, OTP Bank JSC, Citibank PJSC, Ukreximbank JSC, PUMB PJSC, Privatbank CB JSC, Alfa Bank OJSC, Kredobank OJSC, Pivdenny Bank PJSC. In particular, for the first half of 2019 (in terms of the acquisition of government bonds), the first three include such banks as Citibank OJSC, Oschadbank JSC and Ukrgasbank JSB.

Stages of the selection of primary dealers

1. The Ministry of Finance reports on the selection of primary dealers by posting information on its conduct on the official website of the Ministry of Finance no later than 10 working days before it is held.

2. Participants of the established deadline shall submit to the Ministry in one copy: an application for participation in the selection, signed by an officially authorized person and certified by a seal; a document confirming the paid authorized capital equivalent to at least 10 million euros; a certified copy of the license for professional activities in the stock market securities trading activities; information on the total volume of government bonds, which should be at least 1 billion hryvnias - a certificate provided by the National Bank of Ukraine and certified by its seal (original or copy certified in the prescribed manner).

3. Within the deadline set after completion of the filing of documents, the commission for the selection and evaluation of the functioning of primary dealers shall evaluate the participants. Volumes of purchase of government bonds in the amount of 1 million hryvnia are estimated as 0.001 points provided that the total volume of trade in government bonds is not less than 1 billion hryvnia. The results of the selection and evaluation of participants are announced by posting on the official website of the Ministry of Finance.

4. Based on the results of the selection, the participants who have passed the selection conclude agreements on cooperation in the government securities market. 
5. The Ministry of Finance informs the National Bank of the selection winners in order to ensure their participation in government bonds in accordance with the NBU Decree of June 18, 2003 No. 248 (as amended).

In order to provide opportunities for the placement of temporarily free funds of local budgets through the acquisition of government securities, which currently have a higher return than bank deposits, the Cabinet of Ministers of Ukraine approved the Procedure for the placement of temporarily free funds of local budgets through the purchase of government securities (resolution of the Cabinet of Ministers of Ukraine dated May 23, 2018 No. 544).

BIGL of Ukraine are government securities placed exclusively on the domestic stock market and confirm Ukraine's obligation to reimburse the bearers of these bonds with their nominal value with payment of income in accordance with the terms of the bonds.

According to the period of circulation of government bonds, there may be: long-term over 5 years; medium-term - from 1 to 5 years; short-term - up to 1 year (3, 6, 9 and 12 months). The nominal value of one government bonds is 1000 hryvnia.

The procedure allows local financial authorities to place temporarily free funds of general and special funds (except for subventions received from other budgets and funds of the reserve fund) by acquiring BIGL with a circulation period of up to one year or more than one year.

The placement of temporarily free funds of local budgets through the acquisition of government securities will increase the efficiency of use of these funds, as well as place them in reliable financial instruments, the payment of interest income and the return of the main amount of which are guaranteed by the state.

According to the Decree of the Cabinet of Ministers of Ukraine dated January 31, 2001 No. 80 "On the issue of domestic government loan bonds", the Ministry of Finance places BIGL in the form of auction sales through the National Bank of Ukraine, which performs public debt servicing operations related to the placement of BIGL, their repayment and payment income from them, and also carries out depository activities in relation to these securities.

BIGL are distributed through initial floatation and additional floatation. By means of initial placement, new bonds are distributed which, under the terms of the issue and the volume of rights granted to their owners, have not yet been circulated.

By extension, bonds are distributed that, by maturity, the size of interest payments, if any, and the amount of rights granted to their owners, comply with the terms of the issue of bonds that are already in circulation.

For placement and additional placement, discount and interest-bearing government bonds are offered. Discount (short-term) government bonds - bonds that are placed at a price below their face value. The yield on a short-term government bond is the difference between the nominal value paid upon maturity of the bond and its acquisition price. Interest (long-term and medium-term) BIGL - bonds for which interest income (coupons) is paid. The interest period is six months.

The Decree of the Cabinet of Ministers of Ukraine "On the issue of domestic government loan bonds" states that the interest rate on short-term BIGL is set at $0 \%$.

Such BIGL are sold to individuals and legal entities on a voluntary basis at a price lower than their face value. The yield on a short-term bond is the difference between the face value, is reimbursed upon maturity, and the purchase price [10].

Medium and long term government bonds have coupons. The coupon period is three or six months (13 or 26 weeks) for medium-term loans and three months for long-term bonds.

Repayment of BIGL and payment of interest income (coupon) occurs on the terms and conditions stipulated during their initial placement. The rate of return on government bonds is set on market conditions when they are placed by the Ministry of Finance with the involvement of the National Bank in accordance with applications submitted by banks - primary dealers, taking into account the requirements of regulatory legal acts on the placement and circulation of government securities. 
The placement of BIGL is carried out on Tuesdays in accordance with the approved schedule, which is posted on the official website of the Ministry in the section "Debt Government bonds", based on the current funding needs of the State Budget of Ukraine. Also, the Ministry's official website contains announcements on the conduct and results of the placement of government bonds. The announcement contains information on the periods of circulation of government bonds, the dates of their placement, repayment and payment of interest income (for interest-bearing government bonds).

To participate in the placement of government bonds, local financial authorities must choose a bank - the primary dealer through a tender and conclude a contract with him for servicing a securities account and a broker service agreement on the government securities market, which should include the conditions for the purchase of government bonds and the possibility of selling them on secondary securities market.

Local financial authorities can only submit non-competitive applications with the determination of the quantity and term of circulation of government securities. Non-competitive applications are satisfied at the weighted average yield of bonds, which is determined during the placement of government bonds and is noted in the results of the placement of government bonds.

For the public, investing in government bonds is a profitable business. This is beneficial because these securities have a high profit margin compared to deposits and other traditional savings instruments. They are also characterized by flexible investment periods, in particular from 3 months to 5 years. An important element of government bonds is that the state guarantees a return on investment. BIGL are not taxed, only a military duty of $1.5 \%$ is paid. It is also attractive that it is possible to invest in government bonds in Ukrainian hryvnia, the euro and the American dollar. This security is a reliable security tool.

The next step in investing in government bonds is to open a bank account in the appropriate currency to pay, receive repayment amounts and pay interest income. Next, you should open a securities account in one of the depository institutions of Ukraine for crediting and storing acquired government bonds. Then it's worth choosing the amount and term of the BIGL for purchase. The next step is to fill out an application for the purchase of government bonds or a dealer contract for the sale. Next, transfer funds to the merchant's account for the acquisition of government bonds. In conclusion, receive a statement from the securities account from the depository institution on the transfer of government bonds. Confirmation of ownership is an extract from the account of the owner of government bonds in securities from a depository institution.

Today there are no real government bonds on paper. They rotate exclusively in electronic form. According to Ukrainian law, everyone can buy bonds of a domestic state loan. However, an individual cannot do this directly in the stock market.

The beginning of 2019 was marked by record sales by the Ukrainian Ministry of Finance of domestic government loan bonds (BIGL). The main buyers, however, contrary to the name of the securities, were foreign investors. Non-residents bought out Ukrainian BIGL for UAH 1-2 billion per week, as a result of which only in January-February non-residents increased their portfolio of hryvnia BIGL by more than $10 \%$, to UAH 12.9 billion. The NBU called the purchase of hryvnia bonds by non-residents one of the factors in strengthening the hryvnia, since foreigners sold the currency in large quantities to buy hryvnia government bonds. True, in mid-March, on the eve of the first round of the presidential election, the massive purchase of government bonds stopped. The hryvnia exchange rate also felt this.

As of September 17, 2019, in Ukraine, the Ministry of Finance raised UAH 2.8 billion to the budget at auctions for the sale of domestic government loan bonds, most of which came from 3-year government bonds. The Ministry of Finance continues to limit the offer of government bonds and thereby reduce the rate of attraction of funds to the state budget. Profitability rates for all government bonds reduced and amounted to:

-for a 3-month government bonds - 16.0\% (decrease by 25 basis points); 
-for 1-year government bonds - 15.29\% (decrease by 23 basis points)

-for a 3 -year government bonds $-15.7 \%$ (decrease by 30 basis points).

In general, the problem of the effective functioning and further development of the securities market in the context of the formation of the financial system of Ukraine can be solved by increasing its liquidity, as a result of such areas of improvement:

-ensuring transparency of the state's activity in issuing its securities and the availability and understandability of the conditions for investing in such instruments;

-improving the organizational basis for the functioning of the domestic government securities market;

-increasing the investment attractiveness of domestic debt obligations of the state;

-increasing investor confidence in the state through the timely and complete fulfillment by state authorities of their obligations related to securities, especially measures with repayment of interest and principal debt.

The problem of the effective functioning and further development of the government securities market in the context of the formation of the financial system of Ukraine can be solved by increasing its liquidity due to such areas of improvement:

-ensuring transparency of the state's activity in issuing its securities, accessibility and understandability of the conditions for investing in such instruments;

-improving the organizational basis for the functioning of the domestic government securities market;

-increasing the investment attractiveness of domestic debt obligations of the state;

-increasing investor confidence in the state through the timely and complete fulfillment by state authorities of their obligations related to securities, and especially measures to repay interest and principal debt $[1 ; 4]$.

In the context of financial engineering, it is worth noting that in Ukraine conditions are being created for the development of the government securities market. In particular, on March 13, 2019, the Clearstream international securities depository and the National Bank of Ukraine signed an agreement on correspondent relations for the further opening of a securities account with the National Bank's depository. Over the past three years, the international securities depository has systematically developed the primary market for government bonds, bringing it in line with international best practices.

Signing an agreement with Clearstream will increase the attractiveness and liquidity of the Ukrainian government securities market. The Cabinet of Ministers of Ukraine has benefited from expanding the range of sources of long-term financing, reducing the cost of debt and improving the foreign exchange structure of public debt due to greater demand for hryvniadenominated securities. So, correspondent relations with Clearstream international depository will ensure the flow of foreign capital into the Ukrainian economy and enhance its financial stability.

It is also worth noting that the placement of part of the government currency government bonds among non-residents has already led to an increase in currency supply on the market, an improvement in the balance of payments, and a slight strengthening of the national currency. As a result, this can cause a corresponding decrease in interest payments on foreign currency debts and a reduction in the budget deficit. In addition, successful placements will reduce the need for the government to attract loans in national currency, and this in turn will reduce their volumes, profitability and, consequently, maintenance costs.

The idea to sell government bonds to the general public has been voiced for a long time, but has never been fully implemented. The fact is that for their real interest, citizens need to sell loan bonds in the so-called documentary form - that is, paper or plastic forms. Otherwise, the meaning for investing in government bonds of Ukraine for the poor Ukrainian is practically lost. In addition, our citizens constantly wanted to sell government bonds exclusively in hryvnia, which, despite the traditional expectations of devaluation and high inflation, was not 
very interesting for ordinary Ukrainian. Another thing is currency government bonds. In real documentary form, they would certainly be in demand. Especially the current yield of $7 \%$.

Conclusions. So, summing up all of the above, we can conclude that Ukraine has a wide range of debt obligations and must take specific measures to increase the level of interest of the population in placing their savings in government securities. In Ukraine, it is necessary, using the best foreign practices of managing government debt securities, to implement effective planning for the issue of government bonds, plan and predict their profitability, disseminate information about the issue in order to attract individuals to purchase and business entities, and determine in the future increase profitability, efficiency, reliability and trust, as well as reducing the riskiness of government debt securities.

\section{Список бібліографічного опису:}

1. Білявська А.Ю. Оцінка перспектив та ефективності ринку державних внутрішніх запозичень. Інфраструктура ринку. Наук. Ж-л. 2018. Вип. 24. С. 334-338

2. Вахновська Н.А., Іщук Л.І., Поліщук В.Г. Сучасні податкові інновації як пріоритетна складова фінансового інжинірингу бізнеспроцесів в Україні. Актуальні проблеми економіки. Наук. Ж-л. 2015. №8. С. 337-342.

3. Вахович I.М., Поліщук В.Г. Фінансовий менеджмент та фінансовий інжиніринг бізнес-процесів: магістерський курс: навч. посіб. Луцьк: В 2-х т. 2-ге вид. Луцьк: СПД Гадяк Жанна Володимирівна; Волиньполіграф, 2014. Т. 2. Поліщук В.Г. Фінансовий інжиніринг бізнес-процесів. $380 \mathrm{c.}$

4. Дохідність ОВДП на первинному ринку. URL: https://bank.gov.ua/control/uk/publish/article?art_id=27843415\&cat_id=44578\#2 (дата звернення: 20.09.2019)

5. Дропа Я.Б. Проблеми та особливості формування кредитних ресурсів держави в умовах глобалізації. Економіка $і$ суспільство. Наук. Ж-л. 2017. Вип. 8. С.579-586.

6. Заруцька О.П. Облігації внутрішніх державних позик в Україні: особливості ціноутворення в умовах недосконалого ринку. Украӥнський соиіум. Наук. Ж-л. 2018. № 1(64). С. 74-94.

7. Коблик І. Внутрішні державні запозичення: оцінка та перспективи розвитку. Науковий вісник НЛТУ України. 2012. Вип. 22.3. С. $222-228$.

8. Могилко Л. Зарубіжний досвід організації внутрішніх ринків державних цінних паперів: перспективи для України. Ринок иінних паперів Украӥни. Наук. Ж-л. 2010. № 9. С. 47-52.

9. Офіційний веб-сайт Міністерства фінансів України URL: https://mof.gov.ua/uk/ovdp (дата звернення: 20.09.2019).

10. Про випуски облігацій внутрішніх державних позик : Постанова Кабінету Міністрів України від 31.01 .2001 № 80. Кабінет Міністрів Украӥни. URL: https://zakon.rada.gov.ua/laws/show/80-2001-\%D0\%BF (дата звернення: 20.09.2019).

11. Процько О.В. Трансформація ринку державних цінних паперів в Україні. Київ, 2015. $210 \mathrm{c.}$

12. Тарасюк М.В., Тімошенко Н.М. Стан і перспективи розвитку інструментарію ринку державних цінних паперів України. Проблеми економіки. Наук. Ж-л. 2018. № 4(38). С. 271-277.

13. Фінансовий інжиніринг: навч. посіб. за ред. О.М. Сохацької. К.: Кондор, 2011. 660 с.

\section{References:}

1. Bilyavska, A.Yu. (2018). Otsinka perspektyv ta efektyvnosti rynku derzhavnykh vnutrishnikh zapozychen' $\lceil$ Assessment of prospects and efficiency of the government domestic borrowing market]. Infrastruktura rynku. - Market infrastructure. Issue 24, $334-338$ [in Ukrainian].

2. Vakhnovska, N.A., Ishchuk, L.I., Polishchuk, V.G. (2015). Suchasni podatkovi innovatsiyi yak priorytetna skladova finansovoho inzhynirynhu biznes-protsesiv v Ukrayini 「Modern tax innovations as a priority component of financial engineering of business processes in Ukrainel. Aktual'ni problemy ekonomiky. - Current problems of the economy. №8, 337-342 [in Ukrainian].

3. Vakhovich, I.M., Polishchuk, V.G. (2014). Finansovyy menedzhment ta finansovyy inzhynirynh biznes-protsesiv: mahisters'kyy kurs [Financial management and financial engineering of business processes: Master's course]. Navchal'nvy posibnyk. - Tutorial. In 2 volumes, 2 nd edition. T. 2. Polishchuk VG Financial engineering of business processes. Lutsk: SPD Hadyak Zhanna Volodymyrivna; Volyn polygraph. 380 p. [in Ukrainian].

4.Dokhidnist' OVDP na pervynnomu rynku [Yields of T-bills in the Primary Market]. URL: https://bank.gov.ua/control/en/publish/article?art id=27843415\&cat id=44578\#2 [in Ukrainian].

5.Dropa, Ya.B. (2017). Problemy ta osoblyvosti formuvannya kredytnykh resursiv derzhavy v umovakh hlobalizatsiyi [Problems and peculiarities of formation of credit resources of the state in the conditions of globalization]. Ekonomika i suspil'stvo. - Economy and society. No. 8, 579-58 [in Ukrainian].

6.Zarutska, O.P. (2018). Oblihatsiyi vnutrishnikh derzhavnykh pozyk v Ukrayini: osoblyvosti tsinoutvorennya v umovakh nedoskonaloho rynku [Domestic government bonds in Ukraine: pricing features in an imperfect market]. Ukrayins'kyy sotsium. - Ukrainian society. No. 1 (64), 74-9 [in Ukrainian].

7. Koblik, I. (2012). Vnutrishni derzhavni zapozychennya: otsinka ta perspektyvy rozvytku [Domestic government borrowing: assessment and prospects]. Scientific Naukovvy visnvk NLTU Ukravinv. - Bulletin of NLTU of Ukraine. No. 22.3, 222-228 [in Ukrainian].

8. Mogilko, L. (2010). Zarubizhnyy dosvid orhanizatsiyi vnutrishnikh rynkiv derzhavnykh tsinnykh paperiv: perspektyvy dlya Ukrayiny [Foreign experience in the organization of domestic markets for government securities: prospects for Ukraine]. Rynok tsinnykh paperiv Ukraviny. - Securities market of Ukraine. 9, 47-52 [in Ukrainian].

9. Ofitsiynyy veb-sayt Ministerstva finansiv Ukrayiny [Official Website of the Ministry of Finance of Ukraine] URL: https://mof.gov.ua/en/ovdp [in Ukrainian].

10. Pro vypusky oblihatsiy vnutrishnikh derzhavnykh pozyk: Postanova Kabinetu Ministriv Ukrayiny vid 31.01.2001 № 80. Kabinet Ministriv Ukrayiny [On issues of bonds of internal state loans: Resolution of the Cabinet of Ministers of Ukraine dated January 31, 2001 No. 80. Cabinet of Ministers of Ukraine]. URL: https://zakon.rada.gov.ua/laws/show/80-2001-\%D0\%BF [in Ukrainian].

11. Protsko, O.V. (2015). Transformatsiya rynku derzhavnykh tsinnykh paperiv $v$ Ukrayini [Transformation of the government securities market in Ukraine]. Kyiv, 210 p. [in Ukrainian].

12. Tarasyuk, M.V. Tymoshenko, N.M. (2018). Stan i perspektyvy rozvytku instrumentarivu rynku derzhavnykh tsinnykh paperiv Ukraviny [State and Prospects for Development of Government Securities Market Instruments in Ukraine]. Problemy ekonomiky. - Problems of economy. No. 4 (38), 271-277 [in Ukrainian].

13. Finansovyy inzhynirynh [Financial Engineering] (2011). Navchal'nyy posibnyk. - Textbook. Ed. O.M. Sochatskaya. K.: Condor, 660 p. [in Ukrainian]. 